Удк 343.21

О.М. Іенатов

кандидат юридичних наук, старший науковий співробітник завідувач кафедри трудового права, права соціального забезпечення та кримінального права Інституту економіки та права (філія) ОУП ВПО “Академія праці та соціальних відносин”,

м. Севастополь

\title{
ОРГАНІЗАЦІЙНО-УПРАВЛІНСЬКІ ФАКТОРИ ПРИХОВУВАННЯ ЗЛОЧИНІВ ВІД ОБЛІКУ
}

Статтю присвячено дослідженню фракторів латентності злочинності. Розглянуто проблеми латентності злочинності, пов'язані з приховуванням злочинів від обліку. Встановлено та надано загальну характеристику організаційно-управлінських факторів приховування злочинів від обліку.

Ключові слова: злочинність, латентність, фрактор, приховування злочинів від обліку.

\section{I. Вступ}

Ефективна протидія негативним соціальним явищам, у тому числі злочинності, передбачає, насамперед, встановлення їх реальних масштабів і стану. Існування прихованої злочинності спотворює уявлення суспільства про фактичний рівень і дійсну структуру злочинності, розмір матеріальних і нематеріальних збитків, завданих суспільству і його членам; ускладнює виявлення основних тенденцій у розвитку злочинності, виявлення фракторів, які її зумовлюють, що, у свою чергу, не дає можливості складати глибокі кримінологічні прогнози і програми боротьби зі злочинністю, зокрема, негативно позначається на розробці загальносоціальних і спеціально-кримінологічних заходів запобігання злочинності і окремим її видам [16, с. 47-48]. У свою чергу, порівняно низький коефіцієнт злочинності в Україні, як слушно зазначив А.Ф. Зелінський, - це результат, насамперед, винятково високої латентності (прихованості) злочинів і погано поставленого обліку [8, с. 111].

Залежно від механізму утворення латентної злочинності, слід виділяти такі її видові класи (групи): 1) природна латентність - сукупність фактично вчинених злочинів, про які ні правоохоронним органам, ні посадовим особам, ні громадянам нічого невідомо; 2) штучна латентність - злочини, відомі окремим громадянам і посадовим особам, але ні ті, ні інші з різних мотивів не повідомляють про них у відповідні органи; 3) латентність як суміжний стан - злочинні діяння, фракт учинення яких став відомий потерпілим чи стороннім особам, але той, хто виявив їх, через неясність ситуації чи неправильну правову оцінку не повідомляє про це в органи кримінальної юстиції; 4) приховування злочинів від обліку - злочини, про які органу, що веде боротьбу зі злочинністю, стало відомо, але його представник з різних причин не реєструє виявлений злочин [21, с. 71-72]. Саме ця класифікація видів лате-

(c) Ігнатов О.М., 2012 нтних злочинів (особливо з урахуванням виокремлення приховування злочинів від обліку), на наш погляд, дає змогу більш повно дослідити фрактори існування як латентної злочинності в цілому, так й окремих видів злочинів. При цьому одним з найбільш складних питань є проблема приховування злочинів від обліку.

Дослідженню латентної злочинності як однієї з найбільш актуальних проблем кримінологічної науки присвячені праці Р.М. Акутаєва, К.К. Горяїнова, І.М. Даньшина, Г.І. Забрянського, А.Ф. Зелінського, О.Г. Кальмана, О.О. Ковалкіна, А.О. Конєва, О.М. Ларіна, Д.А. Лі, В.В. Лунєєва, Г.А. Матусовського, В.Ф. Оболенцева, В.В. Панкратова, В.М. Поповича, О.Г. Фролової, О.С. Шляпочнікова, Т.К. Щеглової та ін. Однак, незважаючи на значну увагу, приділену цій проблематиці, залишається чимало питань щодо рівня латентності злочинності, факторів, що ії̈ зумовлюють, та самого механізму латентизації. Ці питання зумовлені як складністю досліджуваної проблематики, так і динамічністю розвитку соціуму та злочинності як його складової.

\section{II. Постановка завдання}

Метою статті $є$ дослідження проблем латентності злочинності, повязаних з приховуванням злочинів від обліку. Ії̈ новизна полягає у встановленні та наданні загальної характеристики організаційно-управлінських факторів приховування злочинів від обліку.

\section{III. Результати}

Фактори, що детермінують приховування злочинів від обліку, можна поділити на дві окремі групи. До першої групи належать фактори, пов'язані із сумлінністю виконання своїх службових обов'язків окремими працівниками. Ці фактори в цілому збігаються 3 тими, що детермінують латентність злочинів як суміжний (між природною та штучною латентністю) стан [13, с. 215-216], у разі поєднання їх з прагненням працівника, не докладаючи особливих зусиль, що потребує, до того ж, високих професійних якостей, виконати покладений на нього обсяг 
роботи, поліпшити показники, одержати винагороду, просування по службі тощо. При цьому справа може бути не лише у так званих кар'єристських, "службістських" мотивах, а й у прагненні зберегти, виконуючи відомчий план, єдине джерело заробітку, отже, засобів до існування (про що докладніше нижче) тощо.

Тут виникає бажання згадати класиків. Понад 120 років тому Габріель де Тард відзначав: "Зменшення кількості злочинців пояснюється, скоріше за все, похвальною звичкою, що поширюється 3 кожним днем усе більше серед прокурорів, виправляти незначні злочини, довільно відкидаючи деякі обставини, як, наприклад, злом чи проникнення в чуже приміщення, що небагато має значення при крадіжці. ... Перетворені таким чином під час процесу злочинні факти тягнуть за собою значно менше покарання, та притому, якщо обвинувачений віддає перевагу суду присяжних палаті, він завжди має можливість ухилитися від підсудності цьому суду" [24, с. 248]. Отже, протягом століть бажання та вміння "не працювати", властиві частині працівників правоохоронних органів, залишаються незмінними. Змінюються лише домінуюча мотивація та механізм їх практичної реалізації. Так, на жаль, поряд 3 приховуванням злочинів 3 кар'єристських та "службистських" мотивів, останнім часом усе більшого масштабу набуває приховування злочинів з банальних корисних мотивів. Якщо раніше деякі працівники правоохоронних органів застосовували насильство та інші незаконні методи й засоби або приховували певні факти переважно в “інтересах справи”, то сьогодні, крім цього, вони вбачають у такій "роботі" простий та ефективний засіб збагачення. Порушення реєстраційної дисципліни, приховування фрактів та доказів, перекручення фрактів, "порушення-припинення" справи, “правильна" кваліфікація тощо - за певної мети це все ефективний інструментарій отримання протизаконної винагороди та вигоди. Нерідко при цьому страждає не лише справедливість (та вдруге жертва злочину), а й інші не причетні до справи особи.

Безпосередньо приховування злочинів від обліку може відбуватися за допомогою декількох типових прийомів: 1) відмова в прийомі та розгляді заяв і повідомлень про злочини, формалізм і бездіяльність у роботі із заявами (при явному факті вчинення злочинів кримінальні справи взагалі або в день їх вчинення не порушуються, матеріали щодо них передаються оперативним службам, що призводить до зволікання з розслідуванням, тощо); 2) завідомо неправильна правова оцінка події, наприклад, як такої, що не має ознак складу злочину, або як правопорушення; 3) тенденційна підготовка матері- алів дослідчої перевірки по фракту події (спонукання свідків (жертви замаху) до давання відповідних свідчень; нелогічне та вибіркове отримання пояснень щодо факту події тощо); 4) втрата об'єктивних даних, що свідчать про вчинення злочину; 5) підтасування фактів (підміни, спотворення результатів CME тощо); 6) маніпуляції при кваліфікації події (наприклад, типовим $€$ зловживання кваліфікацією діянь, що фактично містять ознаки складу умисного вбивства, як тяжких тілесних ушкоджень, що спричинили смерть потерпілого; при цьому нерідко 3 метою зняття 3 обліку "контрольного" нерозкритого вбивства раніше порушені кримінальні справи, навіть при підтвердженні фактів убивства висновками судово-медичних експертиз та інших обставин, надалі перекваліфіковуються на вчинення тяжких тілесних ушкоджень, що спричинили смерть потерпілого) тощо [13, с. 217]. У цілому ж, як зазначають фрахівці, приховування злочинів відбувається переважно шляхом винесення необґрунтованих постанов про відмову в порушенні кримінальної справи за мотивами відсутності події або складу злочину [5, с. 26]. При цьому, далеко не поодинокими є випадки, коли органом дізнання чи слідства приймається рішення про відмову в порушенні кримінальних справ за надуманими мотивами саме в кінці звітних періодів з метою створення благополучної картини їх розкриття.

До другої групи належать фрактори, пов'язані з недоліками діяльності правоохоронних органів країни в цілому. Саме ці фактори організаційно-управлінського порядку детермінують приховування злочинів на масовому, системному рівні.

Як відомо, приховування злочинів правоохоронними органами від обліку доволі давно практикується в багатьох країнах. Не $є$ винятком, на жаль, і правоохоронні органи України. Як свідчать статистичні дані, останнім часом зростає кількість випадків виявлення порушень обліково-реєстраційної дисципліни (левову частку яких становить незаконна відмова в порушенні кримінальної справи) працівниками ОВС [3]. Так, кількість цих фактів збільшилась з 12042 у 2004 р. до 37458 у 2011 р.! Більше ніж удвічі збільшилась і кількість фактів виявлення безпосередньо укриття (приховування) заяви чи повідомлення про вчинений або такий, що готується, злочин від обліку, що відбувається як шляхом прямого приховування (у більшості випадків, як свідчать форми статистичної звітності останніх років), так і шляхом нереєстрації їх у ЖРЗПЗ чи ЖРІЗ або фальсифрікації матеріалів. Цей показник збільшився 31336 у 2004 р. до 2803 у 2011 р. (рис. 1). 


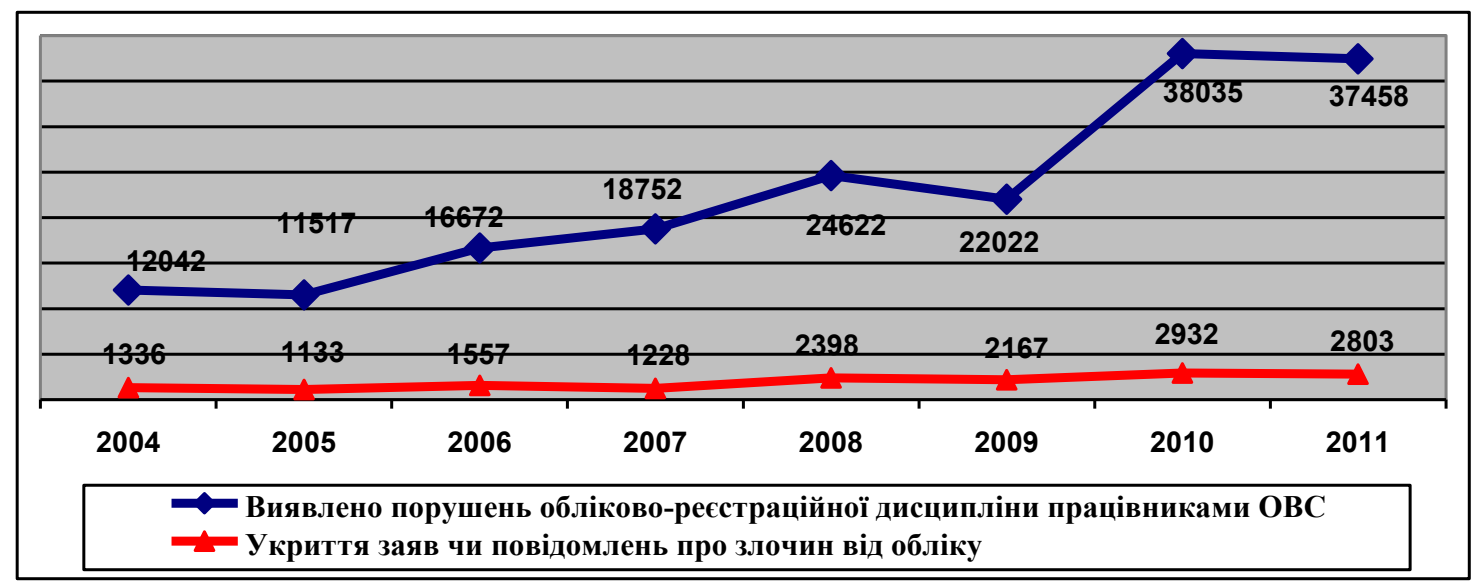

Рис. 1. Динаміка порушень обліково-реєстраційної дисципліни в ОВС України за 2004-2011рр.

Дослідження окремих видів злочинів також вказує на "штучність" тенденцій змін їх рівня та стану. Так, наприклад, проведене нами дослідження показало, що тенденція стрімкого зниження (починаючи з 2001 р.) кількості реєстрованих у країні вбивств не відповідає тенденціям щодо зміни рівня злочинності в країні в цілому. Позитивні зміни у структурі злочинності, зумовлені зменшенням частки реєстрованих у країні вбивств (переважно простих, некваліфрікованих) відбуваються за рахунок її негативних якісних змін, при чому не лише за рахунок збільшення частки кваліфікованих убивств як у структурі вбивств, так й у структурі злочинності в цілому, а й за рахунок украй негативних змін у самій структурі кваліфікованих убивств. Так, збільшення частки кваліфікованих убивств відбувається за рахунок негативних змін у динаміці найбільш тяжких та суспільно небезпечних їх видів та при наявних негативних змінах їх якісних характеристик (збільшення рецидиву, вчинення їх у співучасті, ускладнення способу вчинення, цинізм і жорстокість їх вчинення). Це свідчить про наявні реальні тенденції змін рівня вбивств в Україні та в цілому характеризує як стан тяжкої та особливо тяжкої насильницької злочинності, так і злочинності в країні загалом. Ураховуючи соціальні передумови, специфіку цього виду злочинів, а також певні характерні динамічні зміни стану вбивств у країні, можна зробити припущення про штучність зазначених змін у рівні та динаміці, а також структурі вбивств в Україні, перш за все, пов'язану з маніпулюванням статистичними даними, зокрема, через порушення реєстраційної дисципліни $[10 ; 11]$.

Отже, якщо припустити, що маніпулювання правоохоронними органами статистичними даними щодо рівня та стану злочинності в країні, зокрема через порушення реєстраційної дисципліни, на рівні держави все ж таки наявне, постає питання: чому і яким чином це відбувається? Ключову роль у цьому, на наш погляд, відіграють два моменти: критерії оцінювання діяльності правоохоронних органів [12] та негативні бюрократичні риси фрункціонування останніх [9].

На жаль, сьогодні можна констатувати, що, незважаючи на всі прогресивні перетворення, які відбуваються в нашій країні, у тому числі й у сфері судово-правової реформи, недосконалою залишається система критеріїв оцінювання діяльності правоохоронних органів, зокрема органів внутрішніх справ.

Існування критерію оцінювання діяльності OBC за відсотками реєстрації та розкриття злочинів, що дістався нам у спадщину від радянської політичної системи, у якій міфр про рівень правопорядку в країні був засобом демонстрації населенню спроможності політичного керівництва, руйнівно діє на правоохоронну систему. Нині негативний вплив функціонування критерію оцінки діяльності ОВС за відсотками реєстрації та розкриття злочинів $€$ визнаним фрактом, хоча на недосконалість цього критерію дослідники звертали увагу ще за радянських часів [1; $2 ; 4 ; 6 ; 15 ; 22 ; 23 ; 26]$. Отже, використання цього критерію протягом декількох десятиріч вже довело його недоцільність та недосконалість.

У сучасній світовій кримінології визнається, що рівень правопорядку не $є$ лише результатом діяльності правоохоронних органів, оскільки в суспільстві $€$ й інші фрактори, які регулюють поведінку людей і впливають на динаміку злочинності. Дослідження британських поліцеїстів показали, що поліція взагалі справляє досить обмежений вплив на динаміку злочинності в країні. Саме тому більшість дослідників вважають за доцільне оцінювати діяльність правоохоронних органів за комплексними критеріями, спрямованими на якісний аналіз справ та подальше вдосконалення правоохоронної діяльності. 
Отже, не лише серед науковців, а й у свідомості громадян усе більше закріплюється розуміння того, що спроможність влади у сфері забезпечення правопорядку визначається не лише цифрами статистичних звітів, а рівнем задоволеності населення результатами роботи органів внутрішніх справ, але система критеріїв оцінювання діяльності OBC залишається недосконалою [14, с. 144].

Сьогодні ж ОВС України продовжують звітувати перед суспільством на основі державних статистичних звітів про стан злочинності, де вихідною точкою при оцінюванні результатів діяльності органів внутрішніх справ залишаються зміни динаміки і структури злочинності. Недосконалість такої системи звітності блокує бажання працівників органів внутрішніх справ оприлюднити реальну ситуацію, а тому заважає прийняттю адекватних організаційних і управлінських рішень.

Крім того, в ОВС склалася порочна дисциплінарна практика, відповідно до якої припинення кримінальної справи на підставі відсутності події і складу злочину вважається недоліком у роботі слідчого, оскільки на момент порушення кримінальної справи він не розібрався в наявності або відсутності самого факту вчинення злочину чи причетності особи до вчинення злочину. Таким чином, слідчий підпадає під загрозу притягнення до відповідальності за незаконне порушення кримінальної справи. Це робить його, як правило, особою зацікавленою, він прагне за будь-яку ціну довести винність особи, щодо якої порушена кримінальна справа [18, с. 115]. Вочевидь, такий підхід до оцінювання діяльності ОВС не тільки сприяє зміцненню негативної установки на приховування злочинів від обліку, свідомих, “вигідних" слідчому “помилок” у кваліфікації, а й створює умови для інших, більш тяжких злочинів.

Вивчаючи роль недоліків системи критеріїв оцінювання діяльності правоохоронних органів у латентності злочинності, слід ураховувати й вади матеріально-технічного забезпечення їх діяльності. Як слушно зазначає О.А. Мартиненко, якщо суспільство вимагає високої цифри розкриття злочинів, не забезпечуючи при цьому органи внутрішніх справ ефективними оперативно-слідчими технологіями та відповідними матеріальнотехнічними засобами, виникає група злочинів, пов'язаних з незаконними методами ведення слідства, що мають на меті скорочення розриву між очікуваннями суспільства та результатами поліцейської діяльності [19, c. 225], не кажучи вже про приховування злочинів від обліку як засобу скорочення зазначеного розриву. Таким чином, замість виконання своїх безпосередніх службових функцій у нинішній ситуації працівник орга- нів внутрішніх справ повинен шукати засоби для гідного існування, а щоб не втратити роботу, яка $є$ єдиним за законом джерелом прибутків, усіма доступними йому шляхами й засобами (часом протизаконними) намагається виконати відомчий “план” із розкриття злочинів [14, с. 147].

Щодо негативних ознак функціонування правоохоронних органів, які сприяють маніпулюванню статистичними даними, перш за все, слід відзначити авторитаризм процесу управління та протидію зовнішньому соціальному контролю.

Авторитаризм процесу управління виражається у способі фрормулювання цілей діяльності підрозділів органів внутрішніх справ, результати якої можуть бути вигідні керівництву. Звідси виникає практика "підгонки" показників діяльності під заздалегідь задуманий результат [25, с. 47]. Особливу стурбованість ця проблема викликає у зв'язку з тим, що працівники ОВС відповідають за об'єктивність оцінювання злочинності, маючи можливості маніпулювати її показниками. Такі маніпуляції призводять до латентизації злочинності. Як слушно зауважує О.М. Литвак, $€$ вагомі підстави вважати, що деякий спад рівня злочинності останніми роками (як можемо бачити, за останнє десятиріччя мало що змінилося. - О.І.), який спостерігається у статистичній звітності, є штучним і зумовлений, якщо не кар'єристськими або ідеологічними мотивами, то хибною політикою керівництва правоохоронних органів і неналежною “сумлінністю" виконавців [17, c. 101].

Протидія зовнішньому соціальному контролю багато в чому спричинена тактикоорганізаційним, суто відомчим характером функцій, зумовлених специфікою службової діяльності правоохоронних органів. Режим таємності дає органам внутрішніх справ змогу маніпулювати громадською думкою та за необхідності - підтримувати удавану видимість благополуччя щодо стану злочинності. Брак громадського контролю з боку суспільства дає можливість приховувати злочини, відповідно, слугує однією з передумов існування латентної злочинності.

Не можна не погодитися з позицією, згідно $з$ якою відкритість правоохоронних органів, їх тісний зв'язок з громадкістю $є$ важливою запорукою демократичної трансформації суспільства, його відповідності визнаним цивілізаційним зразкам та еталонам [20, с. 3-4]. Саме тому сучасна європейська практика реформування поліції передбачає наявність не тільки внутрішньої системи контролю за дисципліною і законністю, а й активну взаємодію з громадськими об'єднаннями, що мають за мету здійснення суспільного (зовнішнього) контролю за діяльністю поліції [19, с. 166]. 
Урахування впливу вищезазначених організаційно-управлінських факторів та аналіз сучасного рівня і стану злочинності в країні відповідно до практики її реєстрації дає змогу, на жаль, зробити таке, на наш погляд, цілком обґрунтоване, припущення. Органи внутрішніх справ як бюрократична система, керуючись такими показниками ефективності її діяльності, як кількість зареєстрованих злочинів та рівень їх розкриття, припустилися свідомої системної помилки. Суть її полягає в тому, що в кінцевому підсумку безпосередні виконавці реєструють таку кількість злочинів, розкриття якої вони спроможні практично (з урахуванням вимоги відсотка розкриття, близького до абсолюту, тобто розкриття практично 100\% злочинів) забезпечити.

Завдяки цьому демонструється не лише позитивна динаміка ефективності та успішності роботи органів внутрішніх справ, а й спроможність держави контролювати (принаймні протистояти їй) злочинність у країні (хоча б за допомогою репресивних методів). Однак при цьому створюється міф про стан злочинності, з якою ми “боремося", призводячи до неефективного витрачання часу й ресурсів та поглиблюючи кризовий стан.

На практиці щодо відображення стану та рівня злочинності це відбувається таким чином. Наприклад, щороку в країні реєструється практично така сама кількість убивств, скільки закінчено кримінальних справ цієї категорії. При цьому з року в рік скорочується як загальна кількість убивств, кримінальні справи за якими знаходяться у провадженні OBC, так і кількість справ за вбивствами, розслідування щодо яких закінчено (пропорційно і кількість зареєстрованих убивств) та, відповідно, кількість справ, направлених до суду [7]. Графічно це виглядає так (рис. 2).

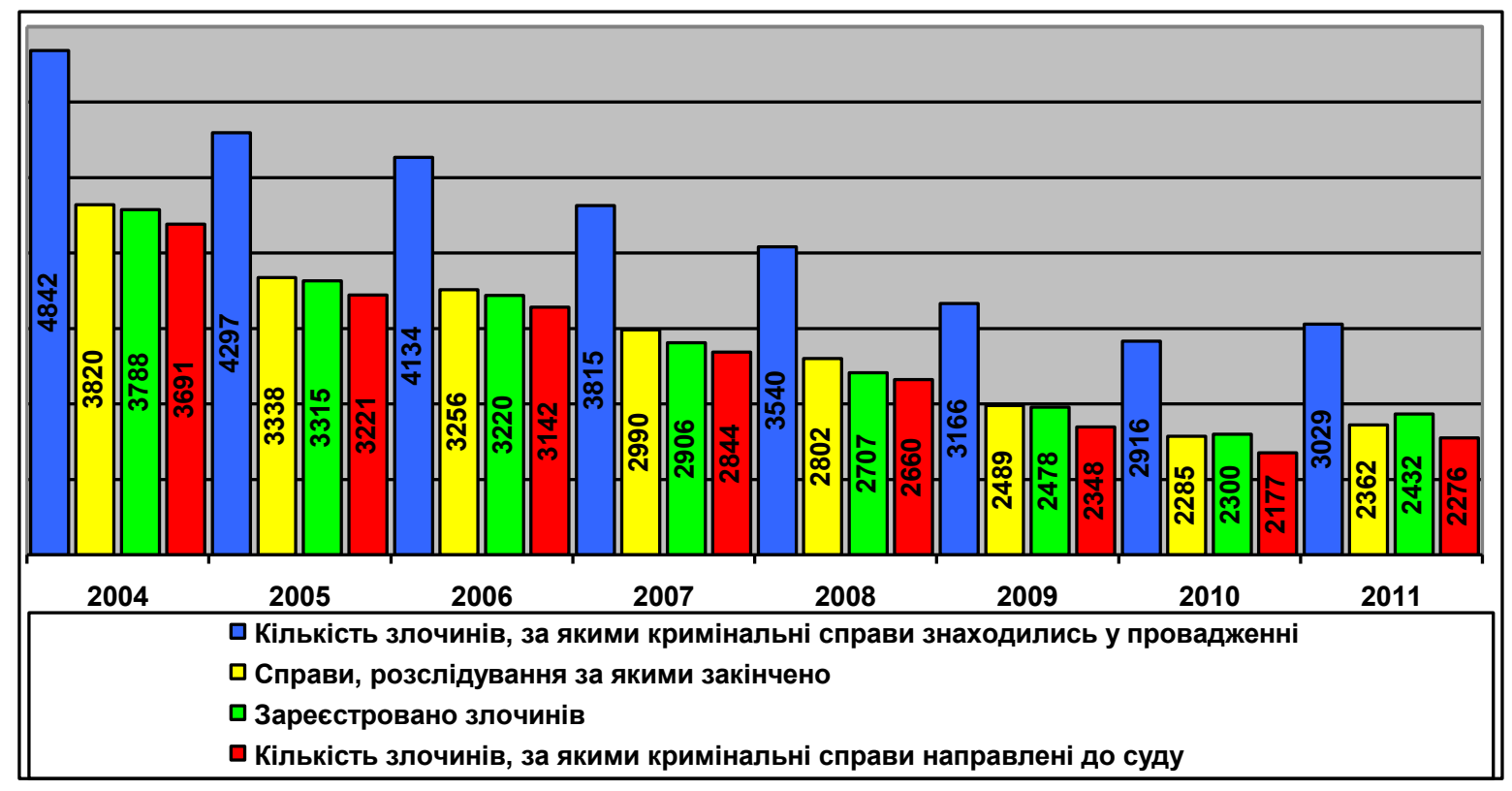

Рис. 2. Стан реєстрації та розслідування умисних убивств (та замахів) в Україні за 2004-2011рр.

Слід зазначити, що відповідний стан справ характерний не лише для України. Як зазначає відомий російський кримінолог Д.А. Шестаков, звичайні передбачені законом "усталені" злочини, про вчинення яких правозастосовчим органам відомо, також далеко не повною мірою потрапляють до державної звітності. Не можна не помітити, що у російської міліції (поліції) з радянських часів збереглася пристрасть штучно створювати видимість зниження кількості злочинів, подаючи таким чином результати своєї роботи з придушення злочинності в “кращому світлі”. Тим самим досягається й інша мета: зменшення навантаження [27, с. 155].

Таким чином, щорічне зменшення показників злочинності корелює зі станом органів внутрішніх справ, правоохоронних органів взагалі, а в кінцевому підсумку, - і держави в цілому. У свою чергу, сучасний стан правоохоронних органів залишає бажати кращого. Політичні та економічні кризові явища суттєво відбиваються на роботі правоохоронних органів і ОВС, зокрема. Невдале затягнуте реформування, неналежна матеріально-технічна забезпеченість, низька конкурентоспроможність та непривабливість служби, скорочення відомчих ВНЗ, повальне омолодження кадрового ресурсу та інші фактори впливають на спроможність, потенціал органів внутрішніх справ реально контролювати злочинність. Падіння цього потенціалу відбивається у штучному "регулюванні" рівня злочинності у країні як засобі самозбереження правоохоронної системи.

\section{IV. Висновки}


Отже, рівень зареєстрованих злочинів у країні відповідає не стільки реальному рівню ураженості злочинністю нашого суспільства, скільки фактичним можливостям (їх межі) правоохоронних органів розслідувати (обробляти відповідну інформацію та приймати рішення) зареєстровані злочини. Тобто падіння відповідного потенціалу відбивається у штучному "регулюванні" рівня злочинності у країні як засобі самозбереження правоохоронної системи.

Ключову роль у приховуванні злочинності шляхом маніпулювання правоохоронними органами статистичними даними щодо рівня та стану злочинності в країні через масове, системне, на рівні держави приховування злочинів від обліку відіграють пов'язані 3 недоліками діяльності правоохоронних органів фрактори організаційно-управлінського порядку. Основними з них є критерії оцінювання діяльності правоохоронних органів та негативні бюрократичні риси функціонування останніх.

Список використаної літератури

1. Беспалов В. Процентная липа / В. Беспалов // Милиция. - 2000. - № 2. C. $45-46$.

2. Бєляков К.І. Оцінка правоохоронної діяльності: теорія та практика / К.І. Бєляков // Боротьба з організованою злочинністю і корупцією (теорія і практика). 2004. - № 10. - C. 106-111.

3. Відомості про порушення обліковореєстраційної дисципліни, що вчинені працівниками органів внутрішніх справ Україні за 2004-2011 рр. (форма 1-3П).

4. Галустян О. Процент раскрываемости и права человека / О. Галустян // Милиция. - 1999. - № 8. - С. 58-59.

5. Горяинов К.К. Латентная преступность в России: результаты исследования и меры борьбы / К.К. Горяинов // Латентная преступность: познание, политика, стратегия: сборник материалов международного семинара. - М. : ВНИИ МВД РФ, 1993. - С. 19-38.

6. Гришанин П.Ф. Пути укрепления законности в практике квалификации преступлений / П.Ф. Гришанин // Советское государство и право. - 1985. - № 1. С. 53-54.

7. Звіт МВС про злочинність (форма № 1) за 2004-2011 роки.

8. Зелінський А.Ф. Кримінологія : навч. посіб. / А.Ф. Зелінський. - Х.: Рубікон, 2000. $-260 \mathrm{c}$

9. Ігнатов О.М. Деякі фрактори латентної злочинності працівників міліції: шляхи їх усунення / О.М. Ігнатов // Право України. -2005 . - № 11. - С. 52-55.

10. Ігнатов О.М. Кримінологічний аналіз рівня та динаміки вбивств в Україні [Електронний ресурс] / О.М. Ігнатов // Форум права. - 2011. - № 4. - С. 314-326. Режим доступу: http://www.nbuv.gov.ua/e journals/FP/2011-4/11iomvvu.pdf.

11. Ігнатов О.М. Кримінологічний аналіз структури вбивств в Україні [Електронний ресурс] / О.М. Ігнатов // Форум права. - 2012. - № 1. - С. 375-386. - Режим доступу: http://www.nbuv.gov.ua/e journals/FP/2012-1/12iomsvu.pdf.

12. Ігнатов О.М. Щодо критеріїв оцінки ефективності діяльності органів внутрішніх справ / О.М. Ігнатов // Право України. 2008. - № 2. - C. 97-101.

13. Ігнатов О.М. Загальна характеристика факторів латентності вбивств / О.М. Ігнатов // Вчені записки Таврійського національного університету ім. В.І. Вернадського. Серія “Юридичні науки”. 2011 . - № 2. - Т. 24 (63). - С. 213-219.

14. Ігнатов О.М. Насильницькі злочини, що вчиняються працівниками органів внутрішніх справ України: кримінологічна характеристика, детермінація та попередження : монографрія / О.М. Ігнатов. Х. : Формат Плюс, 2008. - 296 с.

15. Ковальська В.В. Пошук критеріїв ефективності діяльності органів внутрішніх справ / В.В. Ковальська // Вісник Національного універсітету внутрішніх справ. 2002. - № 17. - С. 147-150.

16. Кримінологія: Загальна та Особлива частини: підруч. для студ. юрид. спец. вищ. навч. закл. / І.М. Даньшин, В.В. Голіна, О.Г. Кальман, О.В. Лисодєд ; за ред. проф. І.М. Даньшина. - Х. : Право, 2003. -352 c.

17. Литвак О.М. Державний контроль за злочинністю (кримінологічний аспект) : дис. на здобуття наук. ступеня д-ра юрид. наук: спец. 12.00.08 / О.М. Литвак. - Х., 2001. - 370 с.

18. Маляренко В.Т. Перебудова кримінального процесу України в контексті європейських стандартів: теорія, історія і практика : дис. на здобуття наук. ступеня д-ра юрид. наук: спец. 12.00.09 / В.Т. Маляренко. - Х., 2004. - 430 с.

19. Мартыненко О.А. Детерминация и предупреждение преступности среди персонала органов внутренних дел Украины : монографрия / О.А. Мартыненко. Х. : Изд-во ХНУВС, 2005. - 468 с.

20. Мельник П.В. Концептуальні передумови формування професіоналізму працівників міліції : монографія / П.В. Мельник, Л.В. Терещенко. - Ірпінь : Український фрінансово-економічний інститут, 1998. - 144 c.

21. Оболенцев В.Ф. Актуальні проблеми латентної злочинності: дис. на здобуття наук. ступеня канд. юрид. наук: спец. 12.00.08 / В.Ф. Оболенцев. - Х., 2001. 185 c. 
22. Пасічник В.Л. Визначення критеріїв оцінки діяльності слідчих і в цілому підрозділів слідчих за системою вагомих показників / В.Л. Пасічник, І.В. Бойко // Науковий вісник Національної академії внутрішніх справ України. - 1999. - № 2. C. $185-186$.

23. Проханов Ю. О совершенствовании системы оценки деятельносты органов внутренних дел / Ю. Проханов // Профрессионал. - 2002. - № 1 (45). - С. 2324.

24. Тард Г.Преступник и преступление. Сравнительная преступность. Преступления толпы / Г. Тард ; сост. и предисл. В.С. Овчинского. - М. : ИНФРА-М, 2009. - $391 \mathrm{c}$

25. Черепашкин А.С. Криминологическая характеристика и предупреждение преступлений, совершаемых сотрудниками милиции общественной безопасности : дис. на здобуття наук. ступеня канд. юрид. наук : спец. 12.00.08 / А.С. Черепашкин. - Омск, 2004. - 167 с.

26. Швець М.Я. До питання відбору показників діяльності органів внутрішніх справ у боротьбі із злочинністю / М.Я. Швець // Правова інформатика. - 2003. - № 1. C. $48-50$.

27. Шестаков Д.А. Криминология: Новые подходы к преступлению и преступности: Криминогенные законы и криминологическое законодательство. Противодействие преступности в изменяющемся мире : учебник / Д.А. Шестаков ; предисл. В.П. Сальникова. - 2-е изд., перераб. и доп. - СПб. : Юридический центр Пресс, 2006. - 561 c.

Стаття надійшла до редакції 02.06.2012 p.

\footnotetext{
Игнатов А.Н. Организационно-управленческие факторы сокрытия преступлений от учета

Статья посвящена исследованию фракторов латентности преступности. Рассмотрены проблемы латентности преступности, связанные с сокрытием преступлений от учета. Установлены организационно-управленческие фракторы сокрытия преступлений от учета и дана их общая характеристика.

Ключевые слова: преступность, латентность, фрактор, сокрытие преступлений от учета.

Ignatov A. Organizationally-administrative factors concealment of crimes from an account

The article is devoted research of factors of latentness of criminality. The problems of latentness of criminality, related to the concealment of crimes from an account, are considered. Set organizationallyadministrative factors of concealment of crimes from an account and given their general description.
}

Key words: criminality, latentness, factor, concealment of crimes from an account. 